\title{
EVALUATION OF COCHLOSPERMUM VITIFOLIUM EXTRACTS AS NATURAL DYE IN DIFFERENT NATURAL AND SYNTHETIC TEXTILES
}

\author{
Luis Gerardo Barriada-Bernal',*, Lilia Leticia Méndez-Lagunas², Laura Victoria Aquino-González², \\ Juan Rodríguez-Ramírez ${ }^{3}$, Sadoth Sandoval-Torres ${ }^{3}$, Itandehui Arriaga González² \\ 1 Department of Research on Raw Materials for the Regional Industry, National Council for Science and Technology (CONACYT) - Instituto Politécnico \\ Nacional (IPN), Hornos 1003 Street, Santa Cruz Xoxocotlán, 71230 Oaxaca, Mexico+ \\ 2 Department of Food Technology, Instituto Politécnico Nacional (IPN), Hornos 1003 Street, Santa Cruz Xoxocotlán, 71230 Oaxaca, Mexico+ \\ 3 Department of Drying Technology, Instituto Politécnico Nacional (IPN), Hornos 1003 Street, Santa Cruz Xoxocotlán, 71230 Oaxaca, Mexico+ \\ *Corresponding author. E-mail: Ibarriadab@ipn.mx
}

\begin{abstract}
:
Cochlospermum vitifolium flowers were evaluated as a raw material of natural dye on different fabrics, natural and synthetic. The dyeing process evaluation was performed by CIELa*b* color coordinates analysis. Color fastness was evaluated using the AATCC 61-1B and AATCC 116 methods. The chemical identification of the compounds in the color fraction was carried out by HPLC-MS/MS. The naringenin was determined to be the color compound. Among the natural textiles, the wool presented the best uniformity of dyeing and fixation of color, achieving the best hue when a pre-mordant treatment was used. The combination of sodium and potassium tartrate dye resulted in the best final hue, between the yellow and red regions of the CIELa* $b^{*}$ space $\left(L=49.84, a^{*}=5.41, b^{*}=45.52\right)$. The dyeing of the wool by the sodium and potassium tartrate pretreatment showed the best fastness properties to the laundering test $\left(\Delta E_{a b}=54.56\right)$, as well as in the rub test $\left(\Delta E_{a b}=67.36\right)$. The extract of $C$. vitifolium could be considered as an alternative natural dye for textiles with a protein base (e.g., wool fabrics), obtaining the best results when mordant pretreatment is used.
\end{abstract}

\section{Keywords:}

Cochlospermum vitifolium, color fastness tests, dye, flowers, naringenin

\section{Introduction}

Dyeing is a complex chemical process, involving several physicochemical phenomena, the most important of which is the fixation (by covalent/hydrogen bond or electrostatic attraction) of the dye to the textile molecules [1, 2].

The use of natural dyes is normally limited to a narrow range of hues and exhibits a low-medium color fastness rate [1]. The use of natural dyes by the textile industry has a positive impact on the environment, including lower water and soil pollutions as well as lower toxicity levels on the flora and the fauna. At the same time, natural dyes allow for textiles with functional proprieties, such as protection against UV radiation and bacteriostatic/bactericidal properties [3].

Natural dye applications have been restricted due to low dye fixation rates and poor color strengths, especially for cellulose cotton-based fabrics [4]. Several approaches have been reported to improve the dyeing process, such as chemical and physical surface modification by enzymatic action, plasma, gamma radiation, or cover materials [5-10], modification of solution-surface equilibrium energy [11, 2], modification of the dye activation energy by ultrasonic waves [12-14], and the use of different mordants, tertiary amines/quaternary ammonium compounds (cationization methods), metal/metalloids salts, tannins, and enzymes [15-18]. All these methods try to increase the chemical affinity between the dye and fiber fabric surface, improving a high electrostatic affinity or the covalent bond formation $[19,20]$.

The raw materials used to obtain natural dyes can be divided into agricultural/forestry products and residues from the food and beverage industry [21]. Various phenolic compounds (some aromatic phenolic acids, flavonols, flavones, and condensed tannins), hydroxy indoles, carminic acid, carotenoids, curcuminarin, and some quinones (tectoquinones and dimeric quinones) have been identified as the responsible of the final hue of dyes extracted from vegetables, plant tissues, and/or fruits [22].

Several phenolic compounds (phenolic acids, flavones, and flavonoids) have been identified as responsible for color in various natural dyes and are used to obtain yellow and orange hues [2].

Cochlospermum vitifolium is widely distributed in tropical and subtropical regions of Mexico and Central America [23]. In Mexico, it is known as wild cotton, yellow rosewood, or marshmallow flower [24]. The pharmacological proprieties of the $C$. vitifolium bark have been documented, but there is a limited reference to the use of bark and stems as a dye for cotton-based textiles that has been documented [25]. There is no available information about the use of the floral tissue as a 
source of natural dye, although there are some reports of its use as a food dye in southern Mexico.

Some phytosterols and phenolic compounds have been elucidated from $C$. vitifolium flower extract, including the flavanone family of compounds, which are the compounds of the highest concentration [26, 27].

The objective of this work is to evaluate the effectiveness of the colorful fraction extracted from flowers of $C$. vitifolium as a dye on natural and synthetic textiles.

\section{Materials and methods}

\subsection{Materials}

\subsubsection{Plant material}

Fresh flowers of $C$. vitifolium were collected in the rainforest zone of Oaxaca, Mexico. The floral material was subjected to a drying process at $50^{\circ} \mathrm{C}$ for $24 \mathrm{~h}$, and then, the sepals and the pedicles were removed from the floral structure.

\subsubsection{Textile materials}

Fabric samples, wool (plain weave, $118 \mathrm{~g} \mathrm{~m}^{-2}$ ), American cotton (plain weave, $204 \mathrm{~g} \mathrm{~m}^{-2}$ ), acrylic (plain weave, $475 \mathrm{~g} \mathrm{~m}^{-2}$ ), and cellulose diacetate (satin weave, $98 \mathrm{~g} \mathrm{~m}^{-2}$ ), were purchased from the Mexican Textile Industry (San Ildefonso; Fábrica de Tejidos de Lana Company, EI Valor Company, and DYEXSA Company).

\subsection{Methods}

\subsubsection{Extraction process}

The extraction of the dye was carried out in the following two phases: (i) Water $\left(80^{\circ} \mathrm{C}\right)$ was added to the dried material in a ratio of $1: 5(\mathrm{w} / \mathrm{v})$. The material was macerated for $24 \mathrm{~h}$ at $25^{\circ} \mathrm{C}$. The solid material was removed by filtration. (ii) The filtered solid material was macerated again in a water/ethanol solution $(20: 80, v / v)$ for $24 \mathrm{~h}$ at $25^{\circ} \mathrm{C}$. The solid material was removed by filtration. Both extracts were combined, and then, they were subsequently evaporated under a nitrogen stream $\left(25^{\circ} \mathrm{C}\right)$.

\subsubsection{Pretreatment}

The fabric samples were pretreated with inorganic (sodium and potassium tartrate, copper sulfate, and potassium sulfate) and organic (tannic acid) mordants. The liquor-to-goods (L/G) ratio was $50: 1$. The process was carried out at $80^{\circ} \mathrm{C}$ for $30 \mathrm{~min}$ and stirred at $150 \mathrm{rpm}$; then, the textile matrices were rinsed with distilled water at room temperature $\left(25^{\circ} \mathrm{C}\right)$ to remove the nonadsorbed mordant.

\subsubsection{Dyeing of textile materials}

The fabric samples were dyed at an L/G ratio of 20:1. The amount of the dye (\%owf) was $12.5 \%$; the dye was dissolved in 1 I of deionized water. The dyeing process was carried out at $80^{\circ} \mathrm{C}$ for $60 \mathrm{~min}$ and stirred at $150 \mathrm{rpm}$. The excess nonadsorbed dyeing solution was removed by rinsing the fabric samples with distilled water at room temperature $\left(25^{\circ} \mathrm{C}\right)$. The textiles were dried at $25^{\circ} \mathrm{C}$.

\subsubsection{Textile color measurement}

The measurement was carried out by comparing the hue of the fabric samples before and after the dyeing process. To evaluate the effect of the dyeing process, the CIELa*b* scale was used; the hue differences were determined by the following Eq. (1):

$$
\Delta E_{\mathrm{ab}}=\left[\Delta L^{2}+\Delta a^{2}+\Delta b^{2}\right]^{0.5}
$$

where $\Delta E_{\mathrm{ab}}$ is the total color difference between nondyed and dyed textiles, $\Delta L$ is the luminance difference between nondyed and dyed textiles, $\Delta a$ is the red hue difference between nondyed and dyed textiles, and $\Delta b$ is the blue hue difference between nondyed and dyed textiles.

\subsubsection{Fixation ratio}

The fixation value of the dye absorbed was determined spectrophotometrically according to the methodology of Lewis and Vo [28]. The dye absorption was evaluated at $248 \mathrm{~nm}$ (wave width of maximum absorption). The fixation ratio was determined by the following Eq. (2):

$$
F=\left[\frac{A_{0}-A_{1}-A_{2}}{A_{0}-A_{1}}\right][100]
$$

where $F$ is the fixation ratio, $A_{0}$ is the absorbance of the dyeing liquor at the beginning of the dyeing process, $A_{1}$ is the absorbance of the dyeing liquor after the dyeing process, and $A_{2}$ is the absorbance of the wash-off solutions after the dyeing process.

\subsubsection{Kinetics of the dyeing process}

The reaction rate constant $(k)$ was evaluated by analyzing the reaction order of the dyeing process. The standard affinity of the dye $(-\Delta \lambda)$ was evaluated according to Eq. (3), based on the assumption that the processes of dyeing by natural products are characterized by dispersion-adsorption mechanisms similar to those exhibited by the dispersed dyes [29]:

$$
-\mu=R T\left[\ln \left(\frac{c_{1}}{c_{0}}\right)\right]
$$

where $-\mu$ is the standard affinity $\left(\mathrm{kJ} \mathrm{mol}^{-1}\right), C_{1}$ is the concentration of the dye in the liquor after dyeing process $\left(\mathrm{mol} \mathrm{I}^{-1}\right), C_{0}$ is the concentration of the dye in the liquor before dyeing process $\left(\mathrm{mol} \mathrm{l}^{-1}\right), R$ is the constant of the ideal gases (8.314 $\left.\mathrm{J} \mathrm{mol}^{-1} \mathrm{~K}^{-1}\right)$, and $T$ is the temperature $(\mathrm{K})$. 


\subsubsection{Color fastness to laundering of textiles}

The color fastness was carried out using a launderometer. AATCC $61-1 B^{*}$-modified methodology was used [30]. The modifications consisted of the use of a solution of TritonX-100 of a concentration of $72.9 \mathrm{mg} \mathrm{ml}^{-1}$ as an anionic detergent; no powder detergent was added. The effect of the washing process was quantified by the difference of the color between the fabric samples before and after the washing process, according to Eq. (1).

\subsubsection{Color fastness to crocking}

The color fastness was carried out using a crockmeter. The AATCC 116 methodology was used [31]. The rubbing effect was quantified by the difference between the fabric sample before and after the washing process, according to Eq. (1).

\subsubsection{Structural dye evaluation}

The dye (aqueous dyeing solution) was subjected to a column chromatography separation process (40-mesh silica gel; SigmaAldrich, USA) by the methodology described by Xenofonte de Almeida et al. [27]. The effluent of the compounds was carried out using solutions of decreasing polarity: $\mathrm{C}_{6} \mathrm{H}_{12}-\mathrm{CH}_{2} \mathrm{Cl}_{2}$ $(1: 0 \rightarrow 0: 1)$ and $\mathrm{CH}_{2} \mathrm{Cl}_{2}-\mathrm{C}_{4} \mathrm{H}_{8} \mathrm{O}_{2}(1: 0 \rightarrow 0: 1$, colored fraction).

The fractions of interest were evaluated using liquid chromatography-positive ion-ESI-MS using a $\mathrm{C}_{18}$ column (150 mm x $2.0 \mathrm{~mm}, 3 \mu \mathrm{m}$; Variant, USA). The chromatographic methodology used was as follows: from 1 to $20 \mathrm{~min}$, a mobile phase was composed of water:methanol:acetic acid (79.2:19.8:1; v/v); at 20-30 min, the methanol concentration was decreased until it reached the composition of methanol:acetic acid:water (49.5:1:49.5; v/v). At the positive ion mode, the needle potential was $4.5 \mathrm{kV}$, the tube lens offset was $-80 \mathrm{~V}$, and the heated capillary temperature was $270^{\circ} \mathrm{C}$. The scan mass spectra were collected in the full scan positive mode (50-700 $m / z)$.

The color phase compounds were identified and analyzed their mass fragmentograms and by direct comparisons of the structural information reported for $C$. vitifolium flower tissues $[26,27]$.

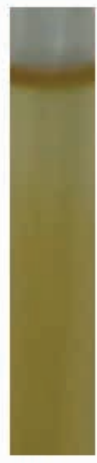

(a)
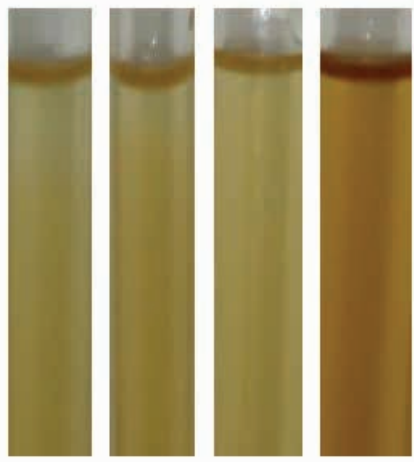

(b)
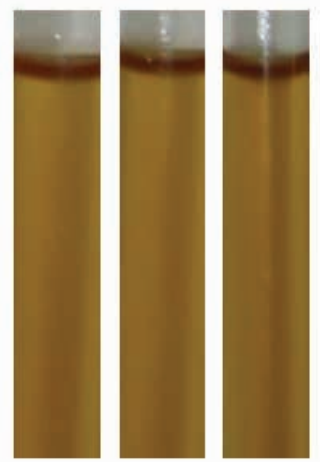

(c)
Figure 1. $\mathrm{pH}$ effect on the color dye solutions. (A) $\mathrm{pH}=1.0$, (B) $\mathrm{pH}=7.0$, and $(\mathrm{C}) \mathrm{pH}=12.0$.

\subsubsection{Statistical analysis}

ANOVA was used; the fabric sample and the type of mordant were factors. The CIELa*b* coordinates, the fixation ratio of the dye, and the color fastness were evaluated as response variables. The statistical analysis was carried out using the Statistica ver.7 software.

\section{Results and discussion}

\subsection{Dye characterization}

The analyses of mass spectra/fragmentogram from the $\mathrm{CH}_{2} \mathrm{Cl}_{2}-\mathrm{C}_{4} \mathrm{H}_{8} \mathrm{O}_{2}$-eluted fraction (colored fraction) indicate that naringenin, $[\mathrm{M} \cdot \mathrm{H}]^{+}=272.4,1,553.1$, and 147.1 , was the compound of the highest concentration.

\subsection{Dyeing process}

The dye solution from $C$. vitifolium flower tissues produced hues from yellow, under basic conditions, to dark orange, under acid conditions (Figure 1). There was no affinity between the synthetic surfaces (acetate and polyester fabric samples) and the dye extract aqueous solution.

The affinity of the dye extract for the cotton fabric sample was poor, with incomplete dyeing in extension and final steps (Figure 2).

For the wool fabric sample, uniform dyeing was obtained (Figure 3). Due to the nondyeing results in synthetic samples, the evaluations of the dyeing process and fastness probes were only carried out on the wool fabric sample.

The affinity between the textile material and the dye depends on several factors, such as affinity through the formation of covalent bonds, hydrogen bonding, and hydrophobic interactions [15], e.g., in cellulose-based fabric samples, when immersed in polar solutions, the cellulose takes an electronegative character that prevents their dye by anionic

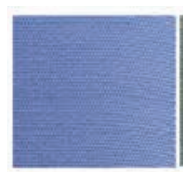

(a)

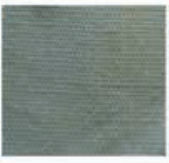

(b)

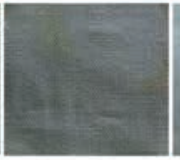

(c)

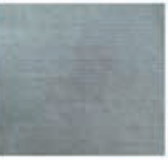

(d)

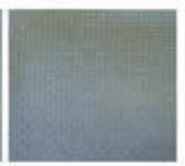

(e)
Figure 2. Cotton dyeing results. (A) Raw cotton, (B) tannic acid pretreatment, (C) sodium and potassium tartrate pretreatment, (D) copper sulfate tartrate pretreatment, and $(E)$ potassium tartrate pretreatment.

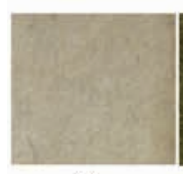

(a)

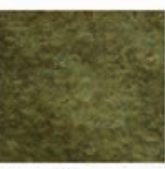

(b)

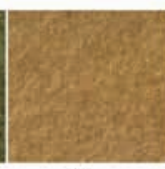

(c)

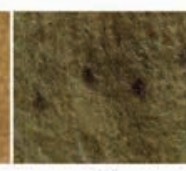

(d)

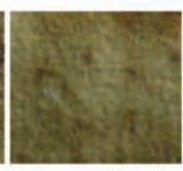

(e)
Figure 3. Wool dyeing results. (A) Raw cotton, (B) tannic acid pretreatment, (C) sodium and potassium tartrate pretreatment, (D) copper sulfate tartrate pretreatment, and (E) potassium tartrate pretreatment. 
reactive dyes. The protein-based fabric samples, such as wool and silk, retain the dyes by hydrogen bonds [32].

The use of sodium and potassium tartrate or tannic acid as a pretreatment generated dye textiles with higher luminosity and hues in the yellow region (Table 1). The copper sulfate and potassium sulfate mordants' pretreatment generated more opaque and hues located near the red region.

The overall effect of the dyeing process (hue) was significantly influenced $(p<0.05)$ by the type of mordant. The tartrate of sodium and potassium salt mordants resulted in better hues $\left(\Delta E_{\mathrm{ab}}=67.71\right)$.

\subsection{Dye fixation efficiency}

The fixation efficiency values (Table 2 ) show that the potassium sulfate generated the best dye fixation ratio $(70.4 \%)$, while the sodium and potassium tartrate generated the lowest dyeing fixation.

\subsection{Dye fastness}

The evaluation of the wool dyed to the rub test (Table 3) indicates that the highest color fastness was observed in the textile pretreated with sodium and potassium tartrate $\left(\Delta E_{\mathrm{ab}}=67.36\right)$, while the pretreatment with cooper sulfate resulted in the higher loss of dye $\left(\Delta E_{\mathrm{ab}}=45.64\right)$.

The results of the evaluation of the dyed wool laundering fastness test (Table 4) indicate that the lower color proprieties were from wool pretreated with cooper sulfate $\left(\Delta E_{a b}=36.73\right)$, while the pretreatment with sodium and potassium tartrate salt resulted in the lower loss of dye $\left(\Delta E_{\mathrm{ab}}=54.56\right)$.

Color fastness and dye fixation are not concepts that describe the same properties. Dye fixation refers to a physicochemical process that depends on the nature of the active sites of the fabric surface molecules, the dye molecule chemical characteristics (a type of functional groups) and physical characteristics (steric hindrances), and the solvation medium used for the dye dispersion (solvent). These characteristics determine the dye absorption, diffusion, and fixation from the solvent to the fabric fibers and the nature of the bonds formed between the dye molecules and the fabric surfaces [33].

Table 1. Mordant pretreatment effect on the wool final hue

\begin{tabular}{|c|c|c|c|c|}
\hline Mordent & $\boldsymbol{\Delta} \boldsymbol{E}_{\mathrm{ab}}{ }^{\dagger}$ & $\boldsymbol{L}$ & $\boldsymbol{a}^{*}$ & $\boldsymbol{b}^{*}$ \\
\hline $\mathrm{KNaC}_{4} \mathrm{H}_{4} \mathrm{O}_{6} \cdot 4 \mathrm{H}_{2} \mathrm{O}$ & $67.71 \pm 0.09^{1}$ & $49.84 \pm 0.28$ & $5.41 \pm 0.01$ & $45.52 \pm 0.25$ \\
\hline $\mathrm{CuSO}_{4}$ & $42.78 \pm 0.30^{2}$ & $36.78 \pm 0.23$ & $2.83 \pm 0.04$ & $21.67 \pm 0.31$ \\
\hline $\mathrm{K}_{2} \mathrm{SO}_{4}$ & $35.45 \pm 0.48^{3}$ & $30.80 \pm 0.52$ & $1.18 \pm 0.05$ & $17.52 \pm 0.15$ \\
\hline $\mathrm{C}_{76} \mathrm{H}_{52} \mathrm{O}_{46}$ & $60.38 \pm 0.35^{4}$ & $43.27 \pm 0.53$ & $1.61 \pm 0.30$ & $42.00 \pm 0.06$ \\
\hline
\end{tabular}

tThe color change, $\Delta E_{\mathrm{ab}}$ is based on the dry and clean color coordinates of the textile.

Different superscripts indicate significant differences $(p<0.05)$ between treatments.

Table 2. Dye fixation efficiency in wool textile

\begin{tabular}{|c|c|c|c|}
\hline Mordent & $\boldsymbol{F ( \% )}$ & $\boldsymbol{K}\left(\mathbf{m i n}^{-1}\right)$ & $-\Delta \mu\left(\mathbf{k J ~ m o l} \mathbf{~}^{-1}\right)$ \\
\hline $\mathrm{KNaC}_{4} \mathrm{H}_{4} \mathrm{O}_{6} \cdot 4 \mathrm{H}_{2} \mathrm{O}$ & $45.61 \pm 0.18^{1}$ & $0.0015 \pm 0.0003$ & $2.18 \pm 0.01$ \\
\hline $\mathrm{CuSO}_{4}$ & $62.61 \pm 0.09^{2}$ & $0.0015 \pm 0.0004$ & $4.21 \pm 0.02$ \\
\hline $\mathrm{K}_{2} \mathrm{SO}_{4}$ & $70.40 \pm 0.04^{3}$ & $0.0015 \pm 0.0002$ & $9.69 \pm 0.10$ \\
\hline $\mathrm{C}_{76} \mathrm{H}_{52} \mathrm{O}_{46}$ & $62.27 \pm 0.13^{4}$ & $0.0015 \pm 0.0008$ & $4.13 \pm 0.03$ \\
\hline
\end{tabular}

Different superscripts indicate significant differences $(p<0.05)$ between treatments.

The potassium sulfate has a higher affinity between the textile and the dye $\left(9.69 \mathrm{~kJ} \mathrm{~mol}^{-1}\right)$.

Table 3. Rub fastness test in wool textile

\begin{tabular}{|c|c|c|c|c|}
\hline \multirow{2}{*}{ Mordent } & \multicolumn{4}{|c|}{ Color CIELa ${ }^{*}{ }^{*}$ coordinates } \\
\cline { 2 - 5 } & $\Delta E_{\mathrm{ab}}{ }^{\dagger}$ & $\boldsymbol{L}$ & $\mathbf{a}^{*}$ & $\boldsymbol{b}^{*}$ \\
\hline $\mathrm{KNaC}_{4} \mathrm{H}_{4} \mathrm{O}_{6} \cdot 4 \mathrm{H}_{2} \mathrm{O}$ & $67.36 \pm 0.53^{1}$ & $48.52 \pm 0.60$ & $1.84 \pm 0.10$ & $46.68 \pm 0.14$ \\
\hline $\mathrm{CuSO}_{4}$ & $45.64 \pm 0.18^{2}$ & $36.63 \pm 0.28$ & $3.40 \pm 0.14$ & $27.01 \pm 0.14$ \\
\hline $\mathrm{K}_{2} \mathrm{SO}_{4}$ & $44.88 \pm 0.25^{2}$ & $35.38 \pm 0.36$ & $1.12 \pm 0.03$ & $27.60 \pm 0.06$ \\
\hline $\mathrm{C}_{76} \mathrm{H}_{52} \mathrm{O}_{46}$ & $66.92 \pm 0.26^{1}$ & $49.93 \pm 0.24$ & $8.40 \pm 0.22$ & $43.76 \pm 0.27$ \\
\hline
\end{tabular}

tThe color change, $\Delta E_{\mathrm{ab}}$, is based on the dry and clean color coordinates of the textile.

Different superscripts indicate significant differences $(p<0.05)$ between treatments. 
Table 4. Laundering fastness test in wool

\begin{tabular}{|c|c|c|c|c|}
\hline \multirow{2}{*}{ Mordent } & \multicolumn{4}{|c|}{ Color CIELa ${ }^{*}{ }^{*}$ coordinates } \\
\cline { 2 - 5 } & $\Delta E_{\mathrm{ab}}{ }^{+}$ & $\boldsymbol{L}$ & $\mathbf{a}^{*}$ & $\boldsymbol{b}^{*}$ \\
\hline $\mathrm{KNaC}_{4} \mathrm{H}_{4} \mathrm{O}_{6} \cdot 4 \mathrm{H}_{2} \mathrm{O}$ & $54.56 \pm 0.86^{1}$ & $35.53 \pm 1.46$ & $6.73 \pm 0.23$ & $70.85 \pm 0.18$ \\
\hline $\mathrm{CuSO}_{4}$ & $36.73 \pm 1.60^{2}$ & $35.94 \pm 1.58$ & $0.63 \pm 0.12$ & $11.86 \pm 0.19$ \\
\hline $\mathrm{K}_{2} \mathrm{SO}_{4}$ & $49.37 \pm 0.61^{3}$ & $36.01 \pm 0.53$ & $31.63 \pm 0.40$ & $12.69 \pm 0.25$ \\
\hline $\mathrm{C}_{76} \mathrm{H}_{52} \mathrm{O}_{46}$ & $49.72 \pm 2.40^{3}$ & $47.96 \pm 2.57$ & $3.25 \pm 0.26$ & \\
\hline
\end{tabular}

tThe color change, $\Delta E_{\mathrm{ab}}$, is based on the dry and clean color coordinates of the textile.

Different superscripts indicate significant differences $(p<0.05)$ between treatments.

The evaluation of the color fastness is one of the most important textile fabric properties. It is a property derived from the dye and the fabric fiber bonds. The fastness refers to the degradation of the fabric color/hue characteristics, under specific conditions, such as exposure to light, water, detergents, or to a specific fabric use condition. The color fastness characteristics determine if the fabric is suitable for the intended purpose. It is an identifying characteristic of the dyeing process. If color fastness is good, then fabric quality is high. Therefore, color fastness is one of the most important quality factors for the buyer to justify choosing a particular dyed fabric.

\section{Conclusions}

The dye extracted from C. vitifolium flower was not able to dye cellulose acetate or polyacrylonitrile fabric samples.

It is possible to dye wool fabric samples with $C$. vitifolium flower extract, using metallic and phenolic mordants to obtain dark orange hues.

Sodium and potassium tartrate salt pretreatment improved the higher color fastness characteristics according to the rub and laundering tests.

The naringenin was identified as the main coloring compound in the flower extracts.

\section{Acknowledgement}

The authors recognize the Operation and Promotion Committee of Academic Activities of the National Polytechnic Institute (COFAA-IPN) for the financial resources for the publication of the manuscript.

\section{References}

[1] Clark, M. (Ed.). (2011). Fundamental principles of dyeing. Principles, processes and types of dyes vol 1. (1 ed.). Padstow (Co.), Woodhead Publishing Series in Textiles (Cambridge).
[2] Zollinger, H. (2003). Color chemistry: synthesis, properties and applications of organic dyes and pigments (3 ed.). Willey-VCH (Cambs).

[3] Bechtold, T., Turcanu, A., Ganglberger, E., Geissler, S. (2003). Natural dyes in modern textile dyehouses - How to combine experiences of two centuries to meet the demands of the future? Journal of Cleaner Production, 11(5), 499-509.

[4] Mao, X. D., Zhong, Y., Xu, H., Zhang, L. P., Sui, X. F., et al. (2018). A novel low add-on technology of dyeing cotton fabric with reactive dyestuff. Textile Research Journal, 88(12), 1345-1355.

[5] Adeel, S, K., Shumaila, R., Sana, A., Tayyaba, R., Fazal, G., et al. (2017). Radiation pretreatment: A potential novel technology to improve fastness properties of plant-derived natural dyes, 1(1), 65-87.

[6] Haji, A. (2017). Improved natural dyeing of cotton by plasma treatment and chitosan coating. Optimization by response surface methodology. Cellulose Chemistry and Technology, 51(9-10), 975-982.

[7] Karanikas, E. K., Kosolia, Ch, Th., Zarkogianni, M, Ch., Nikolaidis, N, F., Tsatsaroni, E, G. (2013). Effect of enzymatic treatment on the dyeing properties of protein woolfibers. Fibers and Polymers, 14(2), 223-229.

[8] Molakarimi, M., Khajeh, M., Haji, A. (2016). Effect of plasma treatment and grafting of $\beta$-cyclodextrin on color properties of wool fabric dyed with shrimp shell extract. The Journal of the Textile Institute, 107(10), 1314-1321.

[9] Muhammad, N. (2018). Plasma treatment as green technology for dyeing of textile fabrics. Trends in Textile Engineering \& Fashion Technology, 2(2), 1-6.

[10] Zhang, J. F., Zhang, X. Q., Fang, K. J., Shu, D. W., Gong, J. X., et al. (2017). Effect of the water content of added cotton fabrics on reactive dye fixation in the pad-steam process. Coloration Technology, 133(1), 57-64.

[11] Haddar, W., Ticha, M., Guesmi, A., Khoffi, F., Durand, B. (2014). A novel approach for a natural dyeing process of cotton fabric with Hibiscus mutabilis (Gulzuba): process development and optimization using statistical analysis. Journal of Cleaner Production, 68(1), 114-120.

[12] Benhi, H., Bahtiyari, M. (2015). Combination of ozone and ultrasound in pretreatment of cotton fabrics prior to natural dyeing. Journal of Cleaner Production, 89(1), 116-124.

[13] Morakotjinda, P., Nitayaphat, W. (2015). Dyeing proprieties and color fastness of chitosan treated cotton fabric whit Thian king leaves extract. Applied Mechanics and Materials, 749(1), 89-93. 
[14] Pan, Y., Wang, W., Gong, K., Hurren, J. C., Li, Q. (2019). Ultrasonic scouring as a pretreatment of wool and its application in low-temperature dyeing. Textile Research Journal, 88(10), 1975-1982.

[15] Fu, S., Hinks, D., Hauser, P., Ankeny, M. (2013). High efficiency ultra-deep dyeing of cotton via mercerization and cationization. Cellulose, 20(6), 114-120.

[16] Haji, A. (2013). Eco-friendly dyeing and antibacterial treatment of cotton. Cellulose Chemistry and Technology, 47(3-4), 303-308.

[17] Hong, K., Bae, J., Jin, S., Yang, J. (2012). Preparation and properties of multi-functionalized cotton fabrics treated by extracts of gromwell and gallnut. Cellulose, 19(2), 507515.

[18] Tsatsaroni, E., Liakopoulou-Kyriakides, M. (1995). Dyeing of cotton and wool fibres with pigments from Crocus sativus-Effect of enzymatic treatment. Dyes and Pigments, 36(3), 215-221.

[19] Prabhu, K. H., Teli, D. (2014). Eco-dyeing using Tamarindus indica $L$. seed coat tannin as a natural mordant for textiles with antibacterial activity. Journal of Saudi Chemical Society, 18(6), 864-872.

[20] Uddin, M. G. (2015). Extraction of eco-friendly natural dyes from mango leaves and their application on silk fabric. Textiles and Clothing Sustainability, 1(1), 1-7.

[21] Ashis, S., Konar, A. (2011). Dyeing of textiles with natural dyes. International Journal of Chemical Technology Research, 5(5), 2102-2109.

[22] Gayo, G. Ma., Arteaga, A. (2005). Análisis de colorantes de un grupo de tejidos hispanomusulmanes. Revista del Instituto de Patrimonio Histórico Español, 5(1), 123-147.

[23] Rzedowski, J. (2006). Vegetación de México, edición digital (1 ed.). Comisión Nacional para el Conocimiento y Uso de la Biodiversidad (Distrito Federal).

[24] Anderson, W. (Ed.). (2001). Ochnaceae to Loasaceae. Flora NovoGaliciana (1 ed.). Ann Arbor (MI), University of Michigan Press (MI).
[25] Cedano, M. M., Villaseñor, I. (2004). Usos y nombres comunes de las especies de Cochlospermaceae en México. Etnobiología, 4(1), 73-88.

[26] Sánchez-Salgado, J., Ortiz-Andradea, R. R., AguirreCrespoa, F., Vergara-Galicia, J., León-Rivera, I., et al. (2007). Hypoglycemic, vasorelaxant and hepatoprotective effects of Cochlospermum vitifolium (Willd.) Sprengel: A potential agent for the treatment of metabolic syndrome. Journal of Ethnopharmacology, 109(3), 400-405.

[27] Xenofonte de Almeida, C., Lêda-Gomes de Lemos, T., Rocha, S., Deusdênia L. (2005). Constituintes químicos voláteis e não-voláteis de Cochlospermum vitifolium (Willdenow) Sprengel. Química Nova, 28(1), 57-60.

[28] Lewis, D. M., Vo, L. (2007). Dyeing cotton whit reactive dyes under neutral conditions. Man-Made Textiles in India, 8(1), 297-308.

[29] Kamel, M. M., EL-Shishtawy, R., Yussef, B., Mashaly, H. (2005). Ultrasonic assisted dyeing: III. Dyeing of wool with lac as a natural dye. Dye Pigments, 65(2), 103-110.

[30] American Association of Textile Chemists and Colorists. (2015). AATCC 61-1B* Method. Colorfastness to Laundering: Accelerated. Retrieved 05, 01, 2019. Web site: $h$ ttps://www.aatcc.org/test/methods/.

[31] American Association of Textile Chemists and Colorists. (2015). AATCC 116 Method. Colorfastness to Crocking: Rotary Vertical Crockmeter Method. Retrieved 05, 01, 2019. Web site: https://www.aatcc.org/test/methods/.

[32] Vankar, P. S. (2000). Chemistry of Natural Dyes. Resonance, 5(1), 73-80.

[33] Shu, D., Fang, K., Liu, X., Cai, Y., An, F. (2018). High dye fixation pad-steam dyeing of cotton fabrics with reactive dyes based on hydrophobic effect. Journal of Natural Fibers, 1(1), 1-11.

[34] Vankar, P. S., Shanker, R., Verma, J. (2007). Enzymatic natural dyeing of cotton and silk fabrics without metal mordants. Journal of Cleaner Production, 15(15), 14411450. 


\section{Mordant pre-treatment effect section.}

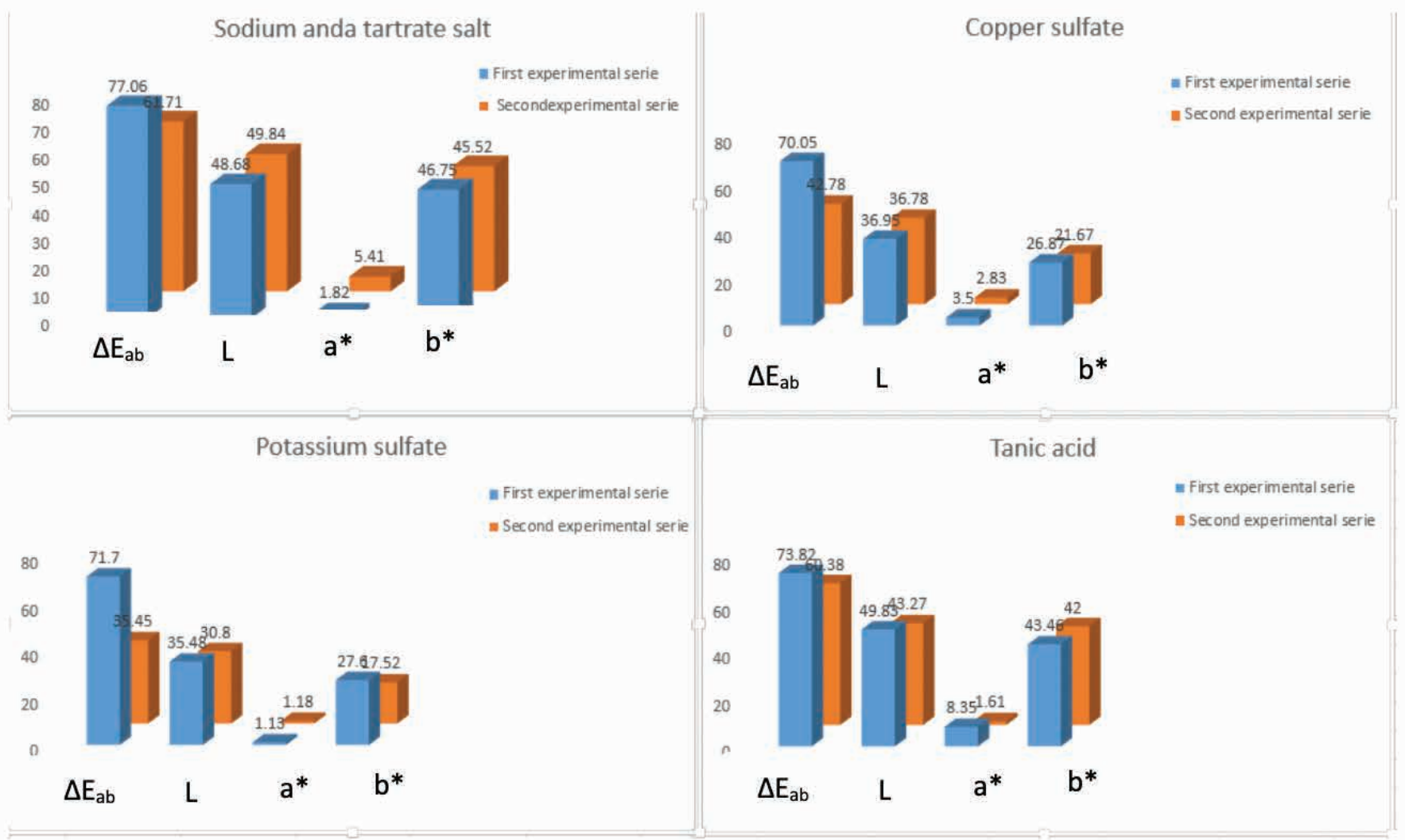

\section{Dye fixation efficiency section.}

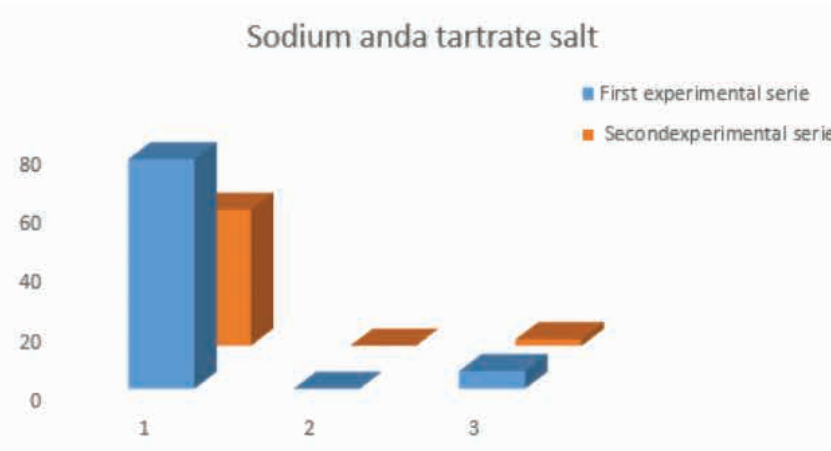

Copper sulfate

- First experimental serie

- Second experimental serie

Potassium sulfate

- First experimenta

serie

w Second experimental

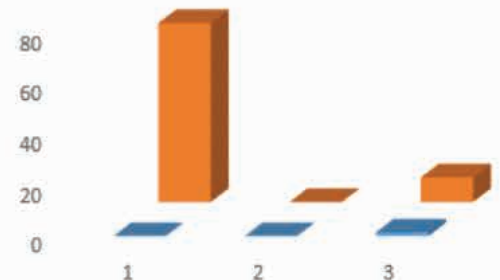

serie
First experimental serie

In Sexond experimental serie

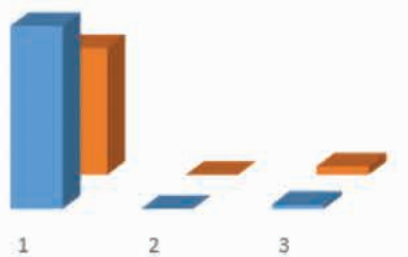




\section{Rub fastness test section.}
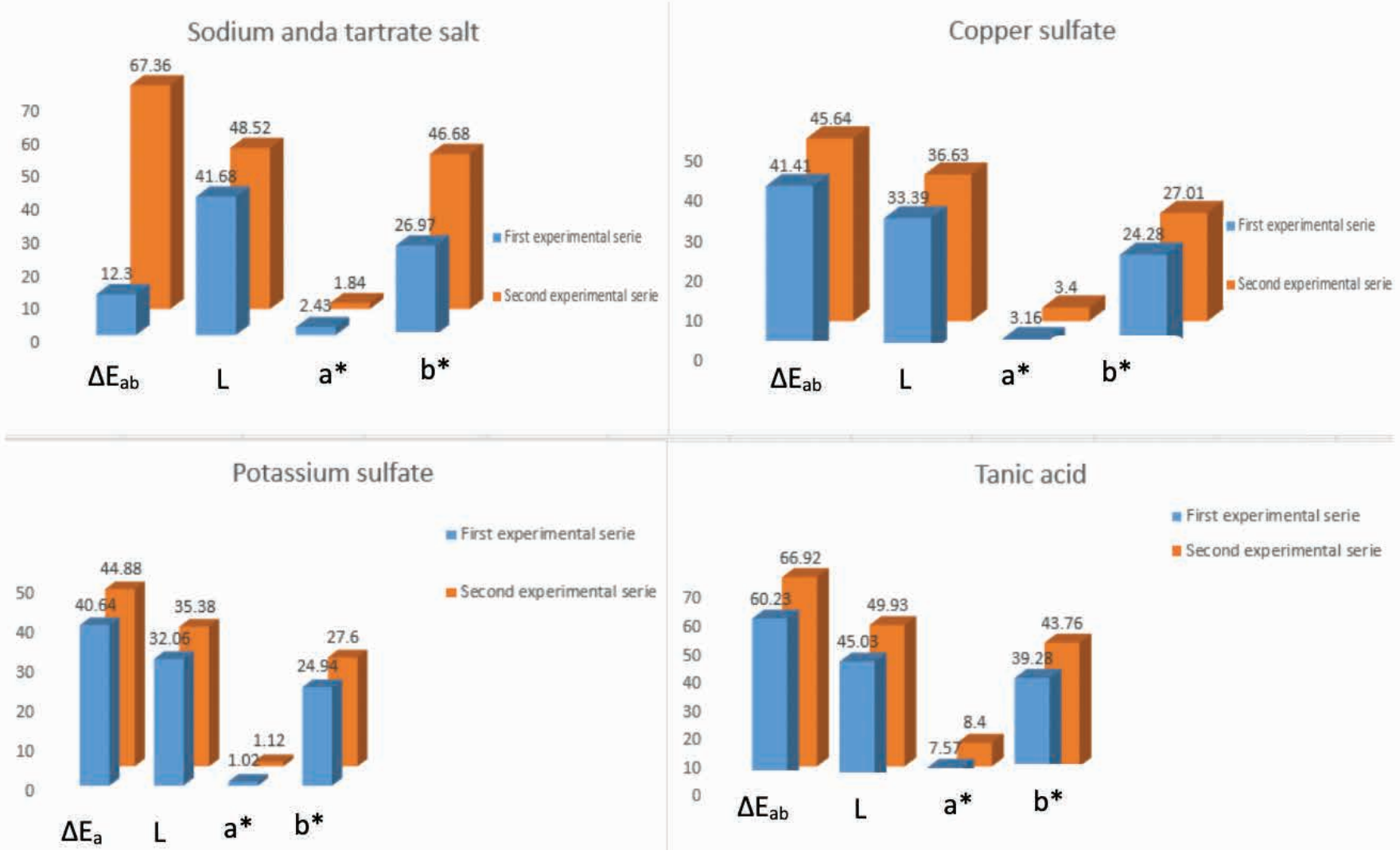

\section{Laundry fastness test section.}
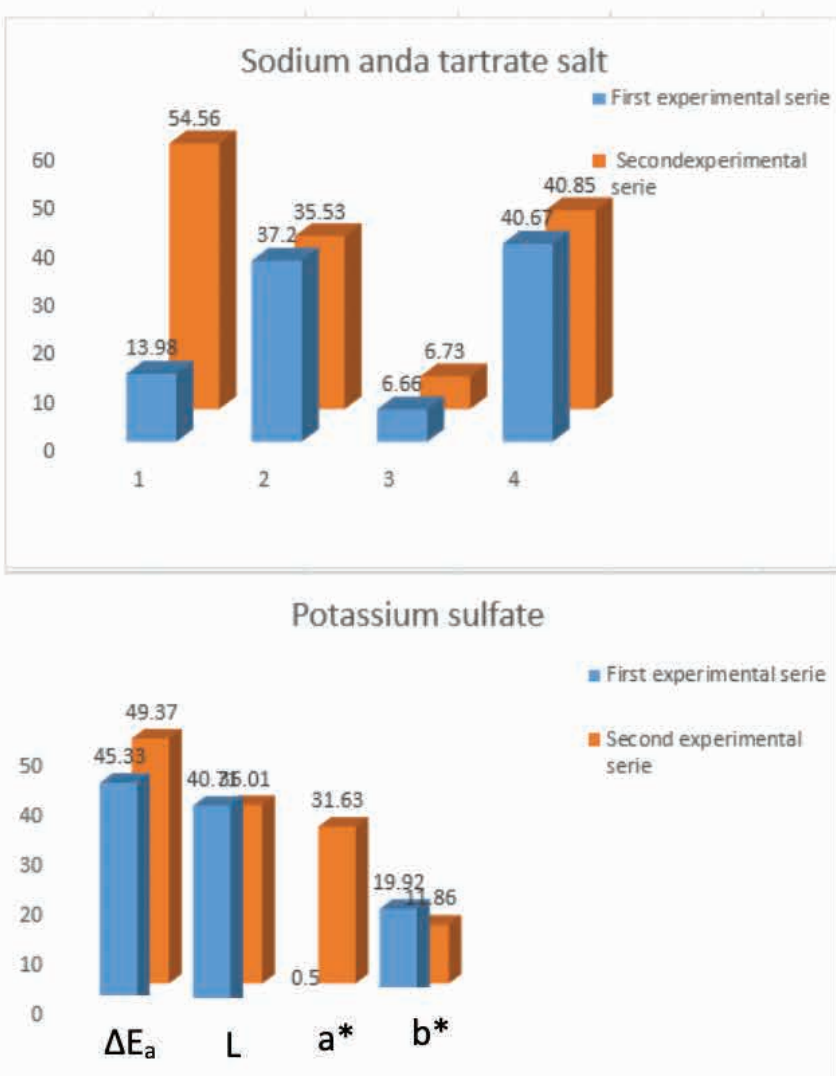

Copper sulfate

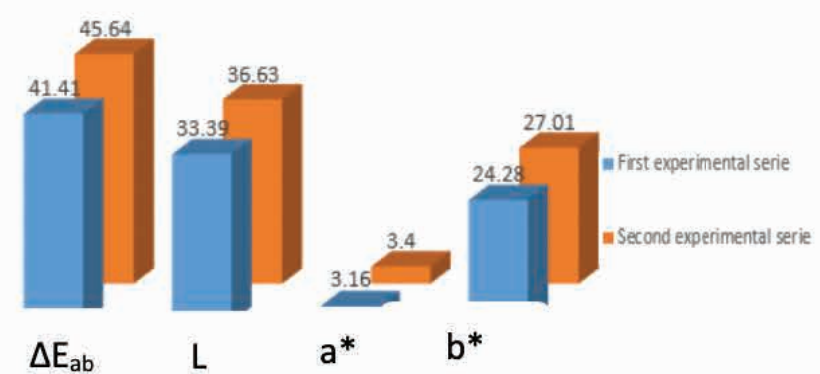


Statistic analysis. Second experimental series

\begin{tabular}{|c|c|c|c|c|c|c|c|c|c|c|c|c|c|}
\hline \multirow[b]{2}{*}{ Cell No. } & \multicolumn{6}{|c|}{$\begin{array}{l}\text { Tukey HSD test; variable Delta } \mathrm{E}_{\mathrm{ab}} \text { (Textiles 2) } \\
\text { Homogenous Groups, alpha }=.05000 \\
\text { Error: Between MS }=.11124, \mathrm{df}=8.0000\end{array}$} & \multirow[b]{2}{*}{ Cell No. } & \multicolumn{6}{|c|}{$\begin{array}{l}\text { Tukey HSD test; variable \%F (Textiles 2) } \\
\text { Homogenous Groups, alpha }=.05000 \\
\text { Error: Between MS }=.01562, \mathrm{df}=8.0000\end{array}$} \\
\hline & Mordant & $\begin{array}{c}\text { Delta } E_{a b} \\
\text { Mean }\end{array}$ & 1 & 2 & 3 & 4 & & Mordant & $\begin{array}{c}\% \mathrm{~F} \\
\text { Mean } \\
\end{array}$ & 1 & 2 & 3 & 4 \\
\hline 3 & 3 & 35.45449 & $\star \star \star \star \star *$ & & & & 1 & 1 & 45.61869 & ***** & & & \\
\hline 2 & 2 & 42.77975 & & $\star \star \star \star \star \star ~$ & & & 4 & $\overline{4}$ & 62.27481 & & $\star * \star \star * *$ & & \\
\hline 1 & 1 & 60.38432 & & & $\star \star \star \star \star *$ & & 2 & 2 & 62.61839 & & & $* * * * *$ & \\
\hline 4 & 4 & $\mid 67.71101$ & & & & $\star \star \star \star \star *$ & 3 & 3 & 70.40923 & & & & $\star \star \star \star \star$ \\
\hline
\end{tabular}

\begin{tabular}{|c|c|c|c|c|c|c|c|c|c|}
\hline \multirow[b]{2}{*}{ Cell No. } & \multicolumn{4}{|c|}{$\begin{array}{l}\text { Tukey HSD test; variable Rub test (Textiles 2) } \\
\text { Homogenous Groups, alpha }=.05000 \\
\text { Error: Between MS }=.11068, \mathrm{df}=8.0000\end{array}$} & \multicolumn{5}{|c|}{$\begin{array}{l}\text { Tukey HSD test; variable Laundering test (Textiles } 2 \\
\text { Homogenous Groups, alpha }=.05000 \\
\text { Error: Between MS }=2.3524, \mathrm{df}=8.0000\end{array}$} \\
\hline & Mordant & $\begin{array}{c}\text { Rub test } \\
\text { Mean }\end{array}$ & 1 & 2 & Mordant & $\begin{array}{c}\text { Laundering test } \\
\text { Mean }\end{array}$ & 1 & 2 & 3 \\
\hline 3 & 3 & 44.88462 & $\star \star \star \star \star$ & & 2 & 36.72939 & & 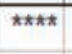 & \\
\hline 2 & 2 & 45.64119 & 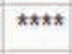 & & 3 & 49.37470 & $\star \star \star \star$ & & \\
\hline 4 & 4 & 66.92229 & & $\star \star \star \star \star$ & 4 & 49.72037 & $\star * \star \star *$ & & \\
\hline 1 & 1 & 67.35711 & & 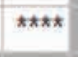 & $1 \|$ & 54.56258 & & & $\star \star \star \star \star *$ \\
\hline
\end{tabular}

\begin{tabular}{|c|c|c|c|c|c|}
\hline \multirow[b]{2}{*}{ Cell No. } & \multicolumn{5}{|c|}{$\begin{array}{l}\text { Tukey HSD test; variable }- \text { Delta u (Textiles 2) } \\
\text { Homogenous Groups, alpha }=.05000 \\
\text { Error: Between MS }=.00307, \mathrm{df}=8.0000\end{array}$} \\
\hline & Mordant & $\begin{array}{l}\text { - Delta u } \\
\text { Mean }\end{array}$ & 1 & 2 & 3 \\
\hline 3 & 3 & -9.69505 & & 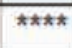 & \\
\hline 2 & 2 & -4.22118 & 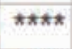 & & \\
\hline 4 & 4 & -4.13668 & $\star \star \star \star \star \star$ & & \\
\hline 1 & 1 & -2.18126 & & & $\star \star \star * \star *$ \\
\hline
\end{tabular}

\begin{tabular}{cc}
\hline & Statistica program code (Cell \\
Mordent & no.) \\
\hline $\mathrm{C}_{76} \mathrm{H}_{52} \mathrm{O}_{46} \cdot$ & 1 \\
$\mathrm{CuSO}_{4}$ & 2 \\
$\mathrm{~K}_{2} \mathrm{SO}_{4}$ & 3 \\
$\mathrm{KNaC}_{4} \mathrm{H}_{4} \mathrm{O}_{6} \cdot 4 \mathrm{H}_{2} \mathrm{O}$ & 4 \\
\hline
\end{tabular}

